\title{
PATCHWORK PLANET
}

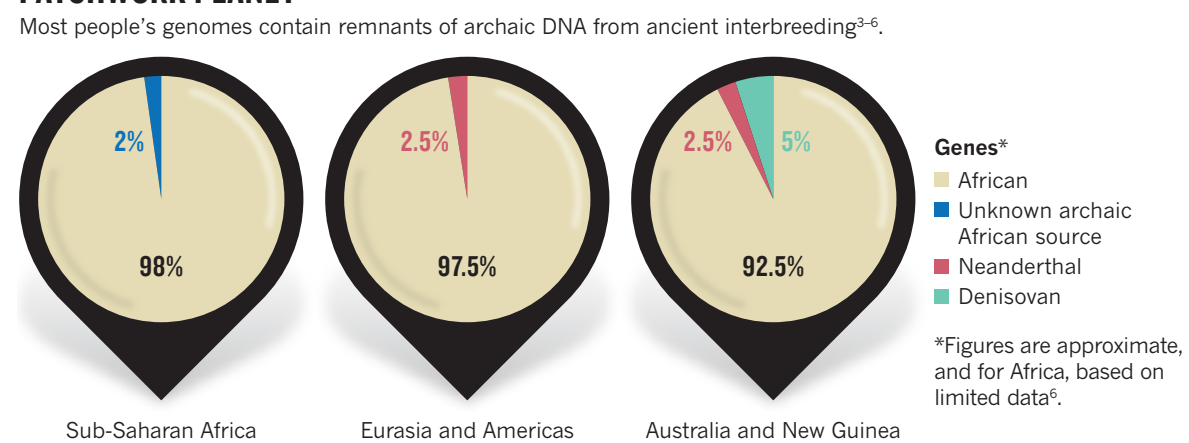

Doing so would produce a species that had a range of morphological variation several times that found in humans today, or in other existing primate species. These human lineages were distinct enough to build up well-differentiated genotypes and phenotypes (although we know little of the Denisovan phenotype so far) - even the inner ear bones of a Neanderthal are readily distinguishable from those of a modern human. Furthermore, many closely related species of primates undergo limited interbreeding, including among our close ape and monkey relatives ${ }^{7}$. So, for pragmatic reasons, I would retain these species categories while recognizing that this does not imply complete reproductive isolation ${ }^{3}$.

It is not yet clear whether the archaic DNA many of us carry is tied to any visible traits. Are some of the regional physical differences that I argue have largely evolved in the past 60,000 years within dispersing modern humans instead the result of Neanderthal or Denisovan genes? Europeans do not seem to have inherited lighter pigmentation or cold adaptation from their Neanderthal predecessors, but what about their large noses or immune systems ${ }^{8}$ ? What about the distinctive teeth and malarial resistance of some Australasians - could these be signs of a Denisovan heritage?

More controversially, some of the known differences in coding DNA between Neanderthals and recent humans are associated with brain development and function ${ }^{4}$. Although the archaeological record of Africa suggests that it was the centre of origin for many innovations in modern human behaviour such as complex tools, symbolism and marine exploitation, some have argued that it was only on leaving Africa that modern humans ratcheted up their cognitive skills in response to the environmental challenges of Eurasia ${ }^{9}$. Now, instead, researchers may start to examine the possible phenotypic expression of Neanderthal, Denisovan or African archaic genes for cognition and intelligence.

Terms such as 'archaic' and 'primitive' may be considered objective when used by palaeontologists, but they can be pejorative in common parlance. If researchers want to continue the progress recently made in studying the origins of modern human variation, they will need to think long and hard about their aims, and the lexicon they use.

One thing should be reiterated: all living humans are members of the extant species $H$. sapiens and, by definition, all must equally be modern humans. The majority of our genes (>90\%) derives from our common African heritage, and this should take precedence over the minor amount of DNA that is different - however and whenever it was acquired. It is important that we examine all the factors that lie behind our evolution, including the possible effects of interbreeding on the physiology of modern humans, but we will have learnt nothing in the past 50 years if we let small segments of distinct DNA govern the way we regard regional variation today. SEE NEWS FEATURE P.23

Chris Stringer is research leader in human origins in the Department of Earth Sciences at the Natural History Museum, London SW7 5BD, UK.

e-mail:c.stringer@nhm.ac.uk

1. Day, M. H. \& Stringer, C. B. L'Anthropologie 95, 573-594 (1991).

2. Wolpoff, M. H. Describing Anatomically Modern Homo sapiens: A Distinction without a Definable Difference. In Fossil Man: New Facts, New Ideas. Papers in Honour of Jan Jelínek's Life Anniversary (eds Novotný V.V. and Mizerová, A.) Anthropos (Brno) 23, 41-53 (1986).

3. Stringer, C. Lone Survivors: How We Came to be the Only Humans on Earth (Times Books, 2012).

4. Green, R. E. et al. Science 328, 710-722 (2010).

5. Reich, D. et al. Nature 468, 1053-1060 (2010).

6. Hammer, M., Woerner, A., Mendez, F., Watkins, J. \& Wall, J. Proc. Natl Acad. Sci. USA 108, 15123-15128 (2011)

7. Jolly C. J. Evol. Anthropol. 18, 275-281 (2009).

8. Abi-Rached, L. et al. Science 334, 89-94 (2011).

9. Kohn, M. The Race Gallery: The Return of Racial Science (Jonathan Cape, 1995).

\section{CORRECTION}

The article 'A plan for mental illness' (Nature 483, 269; 2012) omitted to provide the full list of authors and the conflicting financial interests declared by some of them. This has been rectified online at go.nature.com/t1ihrn. 